Conchustons.

Suoh 18.e brlef abstract of the analysis of all the cases upon which I operated from the beginning of my experience to the end of the year 1905. The result of the inguiry Into the after-history enables certain conclusions to be dxawn which mag galde us in our treatment of the chronle disorders of the stomach in the future. I would sabmit to you the following propositions :

1. Gastro-enterostomy is a ehort-clrcuiting operation, and, like all such procedures, acts best when-a gross mechanlcal obstruction exists in the normal path of the intestinal contents.

2. Experimental work shows that when the pylorus is normal, and there is no impediment to the passage of food through it, the opening made in the operation of gastro. enterostomy does not allow of the escape of any of the gastric contents into the intestine.

3. The operation, therefore, gives the best-results in cases where there is organic disease in the prepgloric or prloric regions of the stomach or duodenum, or when performed on the cardiac side of a stenosis in the body of the otomach.

4. When an ulcer is found on the lesser curvature towards the cardis it ghonld be exclsed if possible; gastroenterostomy is not. necessery, and if performed is elther almost useless or entirely harmful.

5. When there is a-supploion of malignancy in an ulcer or ulcers In the pylorlc region, Rodman's operation should be performed.

6. Under no circumstances, and in compliance with no persuasion however insistent, is gastro-enterostomy to be done in the absence of demonstrable organic disease.

7. Regurgltant vomiting, formerly the most troublesome of all complications, is dependent upon faults in the operation which result in some mechanical obstruction to the intestine. These faults are chlefly dependent upon the presence of a "loop" In the jejunum, but may also be caused by a twist in the intestine around its longitudinal axis at the time of 1 ts application to the stomach.

8. The posterior no-loop operation with the vertical application of the bowel to the stomach is the best procedure.

1 Annals of Surgery, 1906, xliif. 539. \& Arch. f. klin. Chir., 1900, 1xx, 259 , 3 Annals of Surgery, 1905 , xli, 686. 4 Bull. et Mém. de la Soc. de Chir.,
1907, xxxiii, 1250. 5 La Semaine Médicale, 1907, ii, 513.

\section{ERYTHROCYTHAEMIA AND CYANOSIS.}

BY W. P. HERRINGHAM, M.D., F.R.C.P., PHYSICIAN TO ST. BARTHOLOMEW'S HOSPITAL.

A CERTAIN time ago a lady was sent to me for consultation whose case was unusual. She was 38 years of age, and had been a strong woman, fond of taking long walks. She had had no severe lllness, but about six years before she had become very pale, and was told she was ansemic This had given place to a colour higher than natural, and she hisd ever since been subject to attacks of shortness of breath, in which she became very blue. She had'been seen by another physician, who had examined the blood, and had found it polycythaemlc.

She was a rather thin person, but healthy looking, except that her complexion was too florid. Her fingers were rather purple, but not her face. She was breathing rather rapldiy, and as if with some difficulty, but I could not clearly find out why. There was no sign of largnge日 or tracheal or bronchial obstruction; the chest moved falrly, and was resonant; there were no abnormal sounds In the lungs. The breath sounds were a little weak, but not weaker than they are in some healthy chests. The heart's apex was Inside the nlpple line, the sounds clear the pulse regular, and the maximum systolic blood pressure was $120 \mathrm{~mm}$. Hg. Neither liver nor spleen was palpable. The urlne, though turbid with urates, contalned neither albumen nor glucose.

The only complaint beside that of short breath was of extreme constipation, and I at first thought that it might be a case of enterogenous cyanosis. But I could find no indican, which is generally present in the urine when any poison of a putrefactive kind is being absorbed from the intestines.

The blood was examined for me by Dr. Pritchard in the
Clinical Research Department of St. Bartholomew's. He reported :

Count. - Hasmoglobln $=120$ per cent. (Haidane).

Red colls $=7,630,000$ per c.mm. Shape and staining natural ; no abnormal cells seen.

Colour Ind $\in \mathrm{X} \doteq 0.78$.

White cells $=8,800$ per c.mm., namely :

Polymorphonuolears 64 per cent $=5,632$ per o.mm

Lymphooytes $\quad \ldots 25$ " $"=2,200$

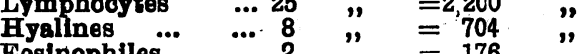

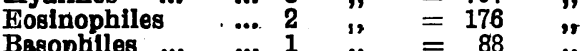

Culture.-Six tubes were: inoculteted; and all remsined sterile.

Spectroscopic Examination:-Dr. H'trtiley: reported : No on adding a reduolng, agent did the band of the latter' appear.

In spite, therefore, of the extreme constipation the blood did not resemble that of enterogenous cyanosis, which shows one of these two abnormal forms of haemoglobin; each of which- is probably due to reducing agents in the blood. Methaemoglobin is regularly thus produced in vitro, and Hurtley ${ }^{1}$ conjectures from his experiments that the same is true of aulph-haemoglobln. Nor did it conform to the splenic form of cyanosis, for though there was a great increase in the red cells there was no enlargement of the spleen.

I was puzzled, and sald so, and a little later the patient came up to a nursing home for further investigation. But two days after her arrival, when she was beginning to menstruate, she was selzed, as was not infrequent at those times, with one of her attacks of dyspnoes. It was chlefly expiratory and was extreme in degree, so that the became very cyanosed. In fact It. was like a veny bad attack of asthma. But it differed from every asthmatic attack that I have ever seen in the entire absence of any slgns that could be relerred to the bronchi. I have never seen asthms without belng able to hear sibllus or rhonchus or râle. In this case there was no such noise. The chest was moving with great efforts, it was highly resonant, and the bresth sounds, especially on the right side, were exceedingly weak. The attacks recurred, and she died In about two days.

I was allowed to make an autopsy. The lungs were emphysematous, but small, and from the larynx to the finest divisions of the bronchl there was no sign of any disease of the air tubes. They were not thickened, and the mucous membrane was free from any secretion. There was a patch of congestion at the left base, where we had heard fine crepltation the day before death. The heart was rather small, neither hypertrophled nor dilated, and free from vavular disease. I was unable to weigh the viscera. The llver was congested, but was not enlarged. The spleen was not enlarged, and seemed natural on section. I regret that the marrow of the long bones was not examined.

I thought at the time that this case was one of atrophlc emphysema in a youngleh person, which had led to polycythaemia in compensation for deficlent aëration. But the more I think of it the less am I satisfied with that explanation. I have seen the red cells much increased in emphrsems, but only when there was much bronchitis and dilatation of the right side of the heart. In the emphysema of old age, which this case resembled, I have not counted the blood, because I have never seen any marked congestion or cyanosis, and I have not been able to find such records in literature.

The other alternative is that it was a case of polycythaemia or erythrocythaemia of the nsual type, but without any splenic enlargement, that the emphysema was a more or less accidental addition, and that the fatal dyspnoes was chiefly due to the state of the blood.

There is a general agreement, I think, that enlargement of the spleen. is of secondary consequence, and is not a cause, but In some way an effect, of the state of the blood. In several Instances the spleen has not been recognized as large during life, and in one or two cases which have been dissected (Cabot, Osler) there appears to have been very little enlargement aiter death. There is: no doubt that enlargement is the rule, but there are exceptlons. I think it is allowable on the evldence to suppose that the disease may exist without any enlargement.

On the other hand, paroxysmal dyspnoes is a symptom that has been recorded in a good many cases. It is rather a surprising symptom under the clrcumstances. It may. 
possibly be due to the viscosity of the blood. Parkes Weber showed this to be much above the natural in his caises, and the observation has been confirmed. But this could only act by delaylng the flow, and when, as In my case, the heart is natural, the pulse regular, and the blood pressure at the usual level, it cannot reasonably be sup posed that the blood is passing the lungs with guch difficulty as to cause dyepnoes.

On the other hand, dyspnoes Is not a natural consequence of a mera Increase in red cells. Rather the contrary. If they were good red cells they would Increase the amount of 0xygen in the blood. It does not seem likely that this would cauge dyspnoes, but the condition has never been reproduced in experiments.

But even if we remain doubtiul about dyspnoea, we can safely asy that the polycythaemia, or erythrocpthaemia would not by itsell cause cyanosis. Now cyanosis is not a constant symptom. Some of the cases are at any rate rather florid than cyanotic. But cyanosis is irequently found, and It has often been notlced that the blood when drawn for examination is very dark. And again, even florid cases become'blue on exertion. How can this be explained? It looks as if, In splte of the erythrocythaemia, and in spite of the amount of haemoglobin, which has been sometimes as high as 180 per cent, there was less oxygen in the blood than usual. I do not think this has ever been measured, but it seems worthy of Investigation, for it seems possible that in this may lie the ecoret of the disease. Suppose for a moment that there is some fault in the crtoplasm or in the haemoglobln of the red cells which prevents them from being good oxygen carrlers, or make the more likely supposition that there is some abnormal reduclng agent in the blood which reduces 0xphaemoglobin but does not turn it into methaomoglobin or sulph-haemoglobin. The want of oxygen might stimulate the bone marrow to form fresh cells, as it does where high altitudes or heart disease Is the cause. This increase of the cells, erythrocythaemla, may be in some cases adequate. There will then be much more blood in the body, but it will be fairly red, though each eell carries less than a healthy cell. These patients will be florjd. In other cases increase in the red cells will not suffice. The iresh cells may be affected from the first with the same llness as the others, or the reducing agent mas be of such power that they cannot counteract it. Then the patlents will be blue. And whether they are floild or blue a little effort, by calling for more oxygen will at once deepen the cyanosis. Even the florld patients will have very little margin.

Such an explanation, which I propose with great diffidence, would not change the part ascribed to the bone marrow. The replacement of the natural marrow by erythroblastic tissue was noticed by Rendu and Widal in 1899 , and they referred the erythrocythaemis to this source. Their observations have been confirmed by Parkes Weber, and, I belleve I am right. In saging, by every observer who has examined the bones.

I am merely supposing that the erythroblastic tissue is stimulated to activity, not by the destruction of red cells, as is suggested by Weber, but by some disease whlch, without destroying them, renders them inadequate for their office. As far as I know, there is no evidence of haemolysis in this disease. The red cells do not, as in perniclous anaemin, vary greatly from the normal. They are nsually described as natural in appearance. A tew normoblasts are occasionally seen, and that is all. Nor has any Iron been found in the viscera, as the result of destruction of the red cells. On the other hand, if there were in the blood an abnormal reducing agent, or even a normal reducing agent in excessive quantity, this disease would be analogous to the conditions of methaemoglobinaemia and sulph-haemogloblnaemia, which is not a great stretch of the Imaglnation.

\section{REFEREACE}

1 Wood Clarke and Hurtley, Journ. of Physiology, xxxvi, 1907, p. 62.

THE report for the year 1907 presented by the Committee of Visitors to the annual meeting of the Royal Institution on May 1st, testified to continued prosperity and efficient management; 41 new members had been elected ; 63 lecturres and 19 evening courses were dellvered, and 896 volumes had been added to the library, including 203 presented. The Duke of Northumberland was re-elected Tresident, and Sir James Crichton-Browne, who presided, Preasarer.
THE RECOGNITION AND TRAINING OF CONGENITAL MENTAL DEFECTIVES.*

By W. A. POTTS, B.A.Cantab., M.D.Edin., M.D.Birm., MEDICAL INVESTIGATOR TO THE ROYAL COMMISSION ON THE CARE AND CONTROL OF THE FEEBLE-MIEDED.

CoNGFiritar mental defectives are not entirely a product of modern clvilization; there can be little doubt, however, that in recent years their numbers have increased out of reasonable proportion to the ordinary population. This Is probably the real resson why public attention has at last been focussed upon them. It Is to be hoped that the report of the Royal Commission on this subject, when Issued, will lead to measures calculated to prevent continued rapld increase in their numbers. The fact that the Sandwell Hall Boarding School for mentally defective children was opened last autumn, and that the Monj hull Colong for mentally defective and eplleptic persons will be ready in a lew days, Indicates that in this district the authorities are alive to the exigencles of the situation, though it is doubtiul whether they have yet fully grappled with the problem. While work such as thls is belng done at home, we find that Canada refuses any longer to be a dumping.ground for wastrels, but will only admit and retain such Individusls as are capable of paying their way and keeplng out of the hands of the police. These considerations emphasize the necessity for recognizing congenital mental defect as early as posslble, and the Importance of being able to forecast whether a particular case can ever be turned loose at home or abroad.

Increasing experience would seem to show that there is no single sign on which a diagnosis can be based; for this purpose both an Intellectual and a physical examination are necessary, together with an Investigation of the attitude and demeanour, and an inquiry into the conduct and mode of life. In many cases the examination can be much curtalled, only a tew intellectual tests being required. The omission of any of the means for detection, however, always involves a posslbility of error; for Instance, a few days ago a boy of 5 was brought to me; he answered questions pretty well for a child of his age, and showed bat little slgn of abnormallty ; I was, however, Informed that he was dirty in hls hablts, and could not be broken of this. As he was in a well-regulated institution, and had been there much longer than is generally necessary to put all right with normal chlldren who are sufferlng from neglect, this fact had much slgnificance. Again, it is matter of common knowledge that chlldren are sometimes branded as feeble-minded when they are only deat or ghort-sighted ; the same mistake may be made with chlldren of 10 or 11 who cannot read or wrlte because the are suffering from such a condition as cardiac disease, whlch has involved never golng to school.

The examination must be adapted to the age of the child. Reading and wilting are, of course, important tests, while the power of calculation must be carefully appraised. W1th young children the objectlve method should be employed; counters, pennies, or matches are always avallable; only the simplest questions are necessary, as a feeble-minded child of 9 or 10 is often unable to add 4 to 7 , if, Indeed, he does not fall with an easier sum. For older children, the number of hallpennles in 80 many pence and the comparative value of three halfpennies and two pennies are useful questions. In the case of adults, the value of half a crown and then of three or four half crowns can be asked; three half-crowns is often the limit of defectives. Arithmetic is a great stumbling-block to weak brains, but slone does not constitute a sufficient test; those who are very weak in other directions are sometimes surprisingly quick at figures. The child mas also be asked-what animal says "bow-wow"? what the cat says? where milk comes from? the use of horses? and so on. Here again with young ohlldren the question should always take an objective form, pictures belng shown in the absence of the real object. Questions on these lines resdily snggest themselves. Colour tests can also be eastly applied, but are of no great value. Ordingyg indivlduals are sometimes colour blind, and among the very poor at least young chlldren are sometimes ignorant of the names even of the fundamental colours, unless they have been taught them at school.

* A paper read at a meeting of the Midland Medical society on April 8th; 1908 . 